\title{
J(ब)
}

\begin{tabular}{||l||c||c||}
\hline \hline Received 19.10.2021 & & JOTS \\
& & $6 / 1$ \\
\hline \hline Accepted 10.11.2021 & Review & $2022: 243-260$ \\
\hline \hline Published 01.01.2022 & & \\
\hline
\end{tabular}

\section{Özçelik, S. Dede Korkut -Günbed Yazmas1- Kazan Bey Oğuznamesi (Giriş-İnceleme-Notlar-Metin-Dil İçi Çeviri- Dizinler), Ankara: Türk Dil Kurumu Yayınları, 2021, ss. 348. ISBN: 978-975-17-4900-0}

\author{
Erdem UçAR* \\ Friedrich-Schiller-Universität Jena (Jena/Germany) \\ E-mail: erdem.ucar@uni-jena.de
}

Veli Muhammed Hoca (1949- ) isimli kitap âşığı bir Türkmen tarafından 2018'de ele geçirilip keşfedilen Dede Qorqut anlatmalarıyla ilgili baştan eksik 31 yapraklık (= 61 sayfa) bir yazma hakkında son dört yılda Türkiye'de, Azerbaycan'da ve İran'da çeşitli neşirler ve çalışmalar yayımlanmıştır. Tanıtımını yapacağımız eser yazmanın Türkiye'de çıkan en son neşridir.

Yeni keşfedilen yazmanın adı eserde Günbed olarak kabul edilmiştir. Günbed, İran'ın Doğu Azerbaycan eyaletindeki Bostanabad şehrine bağlı olan bir köyün adıdır. Ancak yazmayı keşfeden ve yazmanın sahibi olan Veli Muhammed Hoca Günbed-i Kavus [Gonbed-Kâvūs] şehrinde yaşamaktadır. Günbed-i Kavus şehri ise İran'ın kuzeydoğusunda Gülistan eyaletinde yer almaktadır. Eğer yer adı merkeze alınarak bir adlandırma yapılacaksa yazmanın aslının keşfedildiği / saklandığı yerin adının kullanılması ve yazmanın Günbedkavus veya Günbed-i Kavus şeklinde adlandırılmasının daha isabetli olacağı aşikârdır. Ben de daha önceki birkaç çalışmamda yazmayı yazar gibi Günbed ile adlandırmıştım. Uluslararası Dede Korkut Bilgi şöleni ve Deli Dönmez'e Ad Vérme Çalıştayı'nda (11-13 Haziran 2020, Isparta) bazı Dede Qorqut uzmanlarının ortak kararıyla yazmanın Günbedkavus şeklinde adlandırılması gerektiği vurgulanmıştır. Yer adı merkeze

ORCID ID: 0000-0002-0039-9619. 


\section{J(৫)}

alınarak düşünülen Türkmen Sahra şeklindeki adlandırma önerisinin de yanlış olmayacağı şüphesizdir, ancak ben tanıtmamda Günbedkavus şeklindeki adlandırmayı tercih edeceğim.

Eser, Günbed Yazması, Neden Kazan Bey Oğuznamesidir? şeklinde bir sorunun cevabıyla (s. 11-20) başlamaktadır. Bu bölümden, yazmada Qazan Bey dışında herhangi bir Og்uz beyinin Og்uzname'si bulunmadığını, yazmada olayların bir kısmının ozan tarafından diğer bir kısmının da Qazan Beyin ağzından aktarıldığını, bu nedenle metnin Qazan Beyin (oto)biyografisi olarak değerlendirilmesinin yanlış olmayacağını öğreniyoruz.

Eserin başında Kısaltmalar (s. 21) ${ }^{1}$, İşaretler (s. 22) ve Çeviri Yazı Alfabesi (s. 23) kısımları bulunmaktadır. Çeviri Yazı Alfabesi hakkında küçük bir açıklama yapmak gerekiyor. Sunulan tabloda önce Arap harflerinin aslı verilmiş, hemen yanında da büyük ve küçük harflerle onların karşlıkları gösterilmiştir. Bunlardan ikinci sıradaki büyük harfli karşlıkların harfçevrim (transliteration) ve üçüncü sıradaki karşıllkların da yazıçevrim (transcription) olduğu tahmin edilebilir. Tahmin edilebilir diyorum, çünkü tablonun başında hangi sütunun neyi gösterdiğiyle ilgili bir açıklama görülmüyor (Bk. aşağıdaki resim).

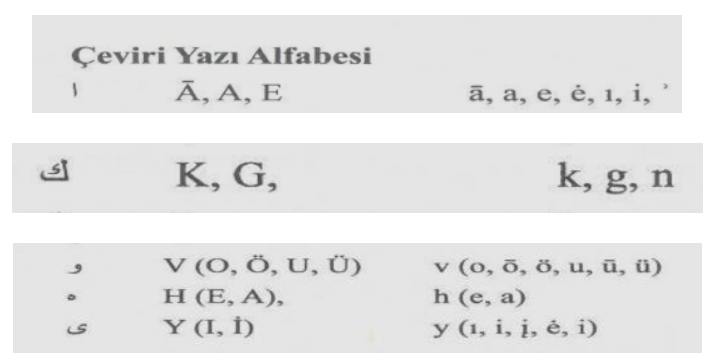

S. 23

Sütunun ikinci sırasındaki büyük harfler Arap harflerinin harfçevrim karşlıklarını gösteriyorsa, bunların aynı anda birden fazla harfi nasıl temsil edebildiği açıklığa kavuşturulmalıdır. Bilindiği üzere, harfçevrim işareti bir yazıdaki harfin başka bir yazıda tek bir harfle temsil edilmesidir. Mesela, yazmada (57/7) şeklinde yazılan kelimeyi yazarın Çeviri Yazı Alfabesi'ne göre harfçevrimle vermeye çalışırsak kelimeyi birkaç şekilde göstermek zorunda kalacağız, zira yazar Arap harflerinin birebir harf karşıllı̆ının olması gereken

Kısaltmalar listesinde eserde sıkça kullanılan ATS kısaltmasının karşıllı̆̆ gösterilmemiştir. ATS, eserin kaynakçasında yer alan S. Altaylı'nın 2018'de neşredilen Azerbaycan Türkçesi Sözlüğü'dür. 
kısımda harf için birden fazla karşıllk göstermiştir. Yazarın tablosuna göre, | ortaya çıkmaktadır. Yazar, elif, kef, vav, he ve ye harfleri için harfçevrim kısmında parantez içinde harflerin yazıçevrimlerini de göstermiştir (bk. yukarıdaki resim), yani harfçevrim ve yazıçevrim birbirine karıştırılmıştır. Eserin İnceleme (s. 57105) bölümündeki izahlarda sorunlu kelimelerin harfçevrimiyle verilmemesi ise başka bir dikkati çeken bir durumdur.

Giriş bölümünün başında şimdiye değin tespit edilen Dede Qorqut Oǵuzname'leri listelenmiștir (s. 25-27). Buna göre, dört adet Dede Qorqut Og்uzname'sine ait yazma olduğunu öğreniyoruz: 1. Dresden yazması; 2. Vatikan yazmas1; 3. Ankara yazmas1; 4. Günbed yazması. Günbed Yazmasinda Soy ve Boyların Sayısı (s. 27-29) başlıklı bölümde, başlık ve açıklama için bazı boş satırların varlığına ve konu bütünlüğüne dayanılarak daha önce ileri sürülen yazmada 21 adet soylama olduğu tespiti yerine 24 adet soylamanın olabileceği tahmin edilmiştir.

Dede Korkut Yazmalarının Okunması Konusunda Hazırlanmış Kitaplar (s. 29-33) kısmında kısaca literatür değerlendirilmesi yapılmıştır. Yazarın sıraladığı eserler listesine Qafarlı \& Rzasoy 2019, Tulu 2020, Azemoun 2020 ile Nağısoğlu 2021 de eklenmelidir. Bunlardan Qafarlı \& Rzasoy'un çalışmasında Günbedkavus yazmasının Dede Qorqut Og்uzname'leri içindeki yeri konusuna farklı bir görüş getirildiğini, Azemoun 2020'de ise yazmadaki sorunlu kelimeler hakkında dikkate değer açıklamaların bulunduğunu özellikle söylemeliyim. Yusuf Azemoun'un doğup büyüdüğü yer Günbed-i Kavus [Gonbed-Kâvūs] olduğu için onun yazma hakkındaki değerlendirmeleri mutlaka hesaba katılmalıdır.

Giriş'in 3. kısmında (s. 33-40) Dede Qorqut anlatmalarının başlıkları ve içerikleri yazmalardaki durumuna göre mukayese edilmiştir. Daha sonra gelen 4 . kısımdaki Ozan, Sözlü Gelenek ve Yazı başlıklı bölüm (s. 40-41) ile 5. kısımdaki Sonsuzluğa Akan Nehir: Dede Korkut Mektebi, Ozan ve Oğuzname bölümü (s. 41-42) ve 6. kısımdaki Dede Korkut Yazmalarının Yazıya Geçirilişi Üzerine başlıklı bölümlerde (s. 43-47), Dede Qorqut anlatmalarının yaratılış süreci üzerinde durulmuştur. Anlatmaların menşei ve yaratılışı meselesinin bugün hâlâ kesin olarak çözüme kavuşturulmadığı malumdur. Daha önce dile getirdiğim bazı tespitlerin (Uçar, 2019: 26-33) bu konuda önemli olduğuna inanıyorum. 
Dede Korkut Yazmalarında Kahramanlarla İlgili Önemli Bilgiler başlıklı 7. kısımda (s. 47-55) yazmalarda kahramanların dikkati çeken özellikleri hakkında tespitler sunulmuştur.

Günbedkavus yazmasındaki kahraman kadrosunda bulunan Qara Budaq'in yazmada uzun bir tasviri vardır. Qara Budaq'in yazmada unvanı şöyle gösterilmiştir: Og̉uz içinde yek qalem éşik aqası başı (4/1-2 ve 25/7). Daha önce vurgulandığı üzere (Shahgoli et al., 2019: 155) bu unvan Günbedkavus yazmasının yazıldığı çevrenin Kaçar hanedanlığı olduğu hakkında bize önemli bir ipucu vermektedir. İran kaynaklarında éşik aǵası başı'nın hükümdarın sarayındaki işlerde adeta sağ kolu gibi bir vazife üstlendiği bilinmektedir (Doerfer, 1965: 184). Dresden ve Vatikan yazmalarındaki Bamsı Beyrek anlatmasına göre, Qara Budaq, Qazan og̉lı Uruz Beg ve Qazılıq Qoca Og்lı Beg Yegenek ile beraber Bayındır Han'ın gözde yiğitlerinden biri olarak karşımıza çıkmaktadır. Günbedkavus yazmasında ise Qara Budaq'in çok daha ayrıntılı tasvirini (3/5 ve $4 / 3$. satırlar ile $24 / 10$ ve $25 / 8$. satırlar arasinda) buluyoruz. Yazmadaki Qara Budaq tasviri ile onun Dresden ve Vatikan yazmalarındaki tasviri [tanımlaması] arasındaki büyük fark düşündürücüdür. Benzer durum Deli Dündar ve Yegenek için de sözkonusudur. Hatta Dresden yazmasında Yegenek'in dayısı Emen olarak anlatılırken, Günbedkavus yazmasında onun dayısı Qazan Bey olarak gösterilmiştir. Yazar, bu durumu Emen adının yanlışlıkla Qazan şeklinde yazılmasıyla açıklamaya çalışmaktadır (s. 55). Böyle bir yazım hatasının olması mümkün değildir. Dresden ve Vatikan yazmalarındaki anlatmaların sözlü ortamı ile Günbedkavus yazmasının sözlü ortamı aynı olmadığı için böyle bir farklılık ortaya çıkmıştır. Günbedkavus yazmasındaki tanımlamaları doğru kabul edip Dresden ve Vatikan yazmalarındaki içerik eksikliklerini (!) Günbedkavus yazmasına dayanarak tamamlamak bence metodolojik bir hatadır. Bu konuyu başka bir makalemde daha geniş ele alacağım için üzerinde fazla durmayacağım.

İnceleme bölümünde (s. 57-72) yazmadaki metnin seslik ve şekil özellikleri kısaca incelenmiştir.

Daha sonra Notlar başlı̆̆ı altında (s. 73-105) yazmadaki bazı yerler hakkındaki açılamaları görüyoruz. Notların bazıları Dresden ve Vatikan yazmalarındaki sorunlu yerleri de içermektedir, zira yeni bulunan Günbedkavus yazması sayesinde Dresden ve Vatikan yazmalarındaki bazı ibarelerin aydınlığa 


\section{ग(৫)}

kavuşması kolaylaşmıştır. Bu bölümde sunulan takdim tehir hatasından kaynaklanan tamir tekliflerinin diğerlerine nazaran daha başarılı olduğu söylenebilir, ancak metindeki eksiklik/atlama olduğu varsayılan yerlerde aynı şeyi söylemek pek mümkün değildir. Mesela, 1.9.'daki Süleymān nebi [pādişah] idi cümlesinde yazar [pādişah] eklemesini yapmıştır (s. 73). Müteakip kısımdaki Dāvud nebi cebedārıdı cümlesinde Dāvud peygamberin mesleğinin zikredilmesi gerekçe gösterilerek böyle bir eklemenin yapılması gerektiği savunulmuştur. Ancak eklenen [pādişah] ibaresi diğer Og்uzname yazmalarında geçmemektedir. $\mathrm{Bu}$ durumda tamamlama teklifinin yegâne dayanak noktası nâşirin kanaati olmaktadir.

G. 3/5'teki sav qullç hakkındaki notta (s. 74-75), yazar daha önce dile getirilen görüşe (Shahgoli et al., 2019: 164) katılır ve bu görüşü destekleyen birkaç izahın neticesinde Dresden ve Vatikan yazmalarındaki üz qulç̧'in 'keskin kılıç' Günbedkavus yazmasındaki karşllığının sav qulıç olduğu neticesine ulaşır. Yazar, notunda 'üz-filinin bir anlamı 'kesmek' olduğuna göre bunun aynı zamanda üz 'keskin' anlaminda bir isim kökü bulunduğundan” bahsetmektedir, ancak üz'ün 'keskin' anlamı ve kullanımı için bir tanık getirmemektedir. Yazarın anlamlandırması bağlama gayet uygundur, ancak üz'ün tanıklanmamış olması akılda soru işareti bırakmaktadır. Azemoun, yazıcının Farsça sāvīden mastarından bozarak sav'1 uydurduğunu düşünmektedir (2020: 644-645, 649). Yazmalarda <AVZ> şeklinde yazılan kelimenin oz $\sim \ddot{z} z$ ve $u z \sim \ddot{z} z$ gibi dört farklı şekilde okunması mümkündür. Alternatif görüş olarak iki ihtimal gündeme getirilebilir. Illk önerim, sav'in Arapça șâftan geldiği varsayılıp Dresden ve Vatikan yazmalarındakileri de öz qulıç 'kendine has, özel kılıç' olarak düşünülüp düşünülmeyeceğidir. İkinci ihtimal olarak burada öz’ün varlığı düşünülebilir. Daha önce Eski Türkçe özel- 'eziyet etmek' üzerinde durduğum makalemde (2017: 1-11), fiilin kökü olan öz’den bahsetmiştim. Clauson, bu öz'ü sözlüğünde üz (II) maddesinde göstermiş (1972: 279b) ve kelimenin asıl anlamının 'destructiveness' [yıkıc1] olabileceğini tahmin etmişti. Eğer Eski Türkçe özel- 'eziyet etmek' hakkındaki köken önerim kabul edilecek olunursa, belki de Dresden ve Vatikan yazmalarında <AVZ> şeklinde yazılan kelime öz olarak okunup kelime 'tahrip edici', dolayısıyla 'çok kesici' anlamında düşünülebilir.

G. 4/3 vd.'deki notta (s. 77-79) Günbedkavus yazmasındaki say ile Dresden ve Vatikan yazmalarındaki qalın’ın ‘saygın, seçkin' aynı olduğu iddia edilmiştir. 


\section{ग(৫)}

Orta Türkçede Moğolca alıntı sayın'ın 'good, true, dignitary, selected' [saygın, seçilmiş] varlığı uzun zamandır bilinmektedir (Kincses-Nagy, 2018: 191-192). Türkçe-Moğolca ilişkileri bağlamında fark edildiği üzere (Ramstedt, 1935: 319b; Räsänen, 1969: 394b) Eski Türkçe saġ ile Moğolca sayın arasında bir ilişkinin olduğu görülüyor. Eğer yazarın iddia ettiği gibi, Günbedkavus yazmasındaki say ile Dresden ve Vatikan yazmalarındaki qalın'ın denk olduğu düşünülecekse, bu anlamda Dede Qorqut anlatmalarının dipnüshasında say'ın bulunması gerektiği varsayımını da hesaba katmak yanlış olmayacaktır.

G. 4/8 vd.'deki notta (s. 79-80) yazmada dört yerde geçen ayındurı kelimesi aydın+durı 'berrak, duru' olarak tahlil edilmiştir. Yazmada, varsayılan aydın kelimesinin dört yerde de dal harfi olmadan yazılması düşündürücüdür. Eğer burada benzer anlamdaki iki kelimeden oluşan bir synonymkompositum sözkonusuysa, ilk kelimeyi ayan ‘belli, aşikâr, net, berrak' (< Arapça 'iyān) olarak düşünmek belki daha doğru olabilir.

G. 5/1'deki ornaç 'halef' notunda (s. 80), Tezcan'ın daha önceki izahı benimsenmiştir. Tezcan, Dresden ve Vatikan yazmalarındaki ortaçum'ları ornaçum olarak düzeltmeyi önerip ornaçı'yı ornaçı < *ornaġuçı < *orna+g்u+çı veya orta+çı şeklinde tahlil etmiş̧ir (2001: 153-154). Tezcan'ın tahmin ettiği gibi kelimenin sonunda bir ünlü düşünmek için aslında bir neden bulunmaz, zira Dresden ve Vatikan yazmalarında teklik I. şahıs iyelik eki $\{+(\mathrm{U}) \mathrm{m}\}$ şeklindedir. Dolayısıyla kelimenin gövdesi *ornaç olmalıdır. Diğer taraftan, Eski Türkçede fiilden isim yapan $\{-(\mathrm{X})$ nç\} ekinin hece yutulmasına maruz kalmasına birkaç örnekte tesadüf ediliyor (Erdal, 1991: 275), mesela sevinç < *sevin-inç, vd. Buna göre, Vatikan, Dresden ve Günbedkavus yazmalarındaki ornaç'in hece yutulması neticesinde şöyle oluştuğu ileri sürülebilir: ornaç < *ornanç < *orun+a-nç.

G. 18/4'teki șuhar oq hakkındaki notta (s. 81-82), șuhar oq'un 'bir tür ok' olduğu belirtilip ibarenin tanıklanamadığı söylenmiştir. Azemoun, yazıcının Arapça șuhāret 'eritilmiş şey, kıkırdak' sözünden șahhār şeklinde bir sîga-yı mübâlaga uydurduğunu düşünmektedir (2019: 644-645). Acaba buradaki șohar < soxar < soq-ar 'delici' olabilir mi? Eğer böyleyse, ibarenin șohar oq şeklinde okunup 'delici, sıradan bir ok' anlamında düşünülmesi gerekmektedir.

G. 20/11'deki notta (s. 84) yazmanın orijinalinde eyesini çınqı teper şeklinde geçen ibarede takdim tehir yanlışlı̆̆ yapıldığı düşünülüp ibare çınqır eyesini teper 


\section{ग(৫)}

şeklinde düzeltilmiştir. Yazar, çınqır'ı Azerbaycan Türkçesindeki çımxır- 'öfkeyle bağırmak' ile ilişkilendirmektedir. Ayrıca eserin dizininde (s. 277a) çınql- fiilini 'öfkeyle kişnemek (Azerbaycan Türkçesi çımxır-)' ile anlamlandırmıştır. Buradaki açıklamadan Azerbaycan Türkçesindeki çımxır-'in yazmada <çYNQYR> çınqır şeklini almasının nedeniyle ilgili bir şey öğrenemiyoruz. Yazarın bahsettiği Azerbaycan Türkçesindeki çımxır- (Orucov et al., 2006/I: 478a) 'çemkirmek' çoğunlukla insanlar için kullanılır. Aynı sözün (?) 'kesik kesik havlamak' (DS/III: 1130b) anlamıla köpekler için kullanımına Anadolu ağızlarında ve Türkmencede rastlanmıştır. Burası için iki tane öneri sunmak istiyorum. Acaba buradaki çınqır Azerbaycan'ın Nuxa (Şeki) ağzındaki çınxır 'sırf, tamamen' (İslamov, 1968: 264) olabilir mi? Ayrıca diğer Azerbaycan ağızlarındaki cımxır için krş. Axundov, 2007: 76b-77a. Bu önerinin bağlama uygun olduğu çok açıktır, zira çınxır cümlede tep- fiilini 'iyice' anlamıyla nitelemiştir. Ancak çınxır'ın yapısı hakkında kesin bir şey söylemek zordur. Belki de çınxır Eski Türkçe çınǵaru 'tam, tamamen' (Wilkens, 2021: 229a-b) kelimesine dayaniyor olabilir. İkinci ihtimal olarak yazarın takdim tehir yanlışlı̆̆ tespitini doğru bulup burada, çınqır $\rightarrow$ çı̇qır<ır> şeklinde bir düzeltme teklif edilebilir. Kelimedeki geniş zaman eki eksik yazılmıştır. Bunun nedeni muhtemelen kelimenin satır sonuna sığdırılmaya çalışılmasıdır. Kelime için krş. Türkmence çıqqur- '(köpekler için) cıyak cıyak ses çıkarmak’ (Kyýasowa et al., 2016/I: 237a). Böyle bir öneriye göre, o zaman metinde çııqır- fiili 'huysuzlanarak kişnemek' gibi bir anlamda olmalıdır. Azmun'un çıøqır- hakkındaki köken önerisi oldukça makul görünüyor. Türkmenlerin kulağına göre köpeğin acı acı çıardığı ses çınq şeklindedir, yani çınq ses yansımalı bir sözdür. Çocuğu susturmak için de cınqı̇ı çıqartma denir. Aynı ifade Azerbaycan Türkçesinde cınǵırıġıı çıxartma şeklindedir. O hâlde, *çııq ur- > *çııqur- > çınqır- 'köpeğin kesik kesik havlaması'. Oġuz grubu Türk dillerindeki çemkir- 'çemkirmek' de belki buna dayanıyor olabilir (Azemoun, 2013: 169, 177). Ancak son tahlilde köpeğin çıkardığı bir sesin at ile ilişkilendirilip ilişkilendirilemeyeceği hakkında kesin bir şey söylenemiyor. Belki de buradaki çı̇qır- fiili Kaşgarînin kaydettiği ses yansımalı çı çay (Clauson, 1972: 424b) kaynaklı olabilir, zira Eski Türkçede ses yansımalı fiillerin yapımında kullanılan bir \{+kIr-\} eki (Erdal, 1991: 465-468) bilinmektedir. O hâlde, çıøqır- < çı1y+qırşeklinde bir tahlil düşünülebilir. 
G. 49/3'teki notta (s. 84) el vérüb elleş- 'savaşmaya kalkışmak' anlamında düşünülmüss, ancak el vérüb elleşmedüm ibaresi metnin dil içi çevirisinde 'el verip davranmadım' ile aktarılmıştır (s. 256). Buradaki sözkonusu ifade Dede Qorqut Oǵuzname'lerinde ortak olarak geçen bir soylamada bulunmaktadır. Bu soylamayı müstakil olarak bir makalemde ele almıştım. Bağlamı esas alıp Türkmence ve Azerbaycan Türkçesindeki tanıklara dayanarak el vérüb elleş-'i 'razı olup el sıkışmak' ile anlamlandırmıştım (2020a: 226-228). Aslında benim de benimseyip gerekçelendirdiğim doğru anlamlandırma ilk kez Azmun tarafından (2019: 84) 'teslim olup tokalaşmadım' şeklinde ortaya konmuştur. Aynı şekilde, Topkapı Oǵuzname'sindeki el vér- deyimi Tezcan tarafından da 'teslim olmak' ile anlamlandırılmıştır (2020: 124, 285b). Yazarın bahsettiği elleş- 'dövüşmek, kavga etmek' yazmanın iki yerinde geçmektedir (13/9 ve 32/4) ve burada fiil yazarın bahsettiği anlamdadır, ancak 49/3'teki elleş- için aynı anlam düşünülemez, zira: 1. Burada elleş- tek başına değil, el vér- ile beraber geçmektedir; 2. Soylamanın bağlamına göre 'savaşmak' anlamı uygun değildir. Yazar, aslında el vér-'i daha önceki Dede Qorqut neşrinde (2016: 842a) Tezcan'ın Tarama Sözlügü̈ne dayanarak teklif ettiği 'teslim olmak' ile anlamlandırmıştı. Yazarın bu kabulüne göre el vérüb elleş-'i anlamlandırmaya kalkarsak 'teslim olup dövüşmedim' gibi anlamsız bir şey ortaya çıkacaktır. Üstelik el vér- 'savaşmaya kalkışmak' için herhangi bir tanık da gösterilmemektedir. Bugün Azerbaycan Türkçesinde el vér- '1. ele ele tutuşmak; 2. işe yaramak; 3. olmak, baş göstermek' (Orucov et al., 2006/II: 86b) ve Türkmencede el vér- '1. yardımcı olmak; 2. razı olmak, rıza göstermek' (Kyýasowa et al., 2016/I: 345a) anlamındadır. Türk dillerindeki anlamların Tarama Sözlüğ̈̈̈'ndeki 'teslim olmak' (TS/III: 1452) anlamıyla uyumlu olduğuna dikkat çekmeliyim. Yazar, Evliya Çelebi Seyahatnamesi'ndeki elleş- 'dövüşmek, kavga etmek' tanığını zikretmektedir, ama Osmanlı Türkçesinde 'birbirinin elini tutmak, el sıkışmak; ağır bir şey kaldırmak için birkaç kişi birden tutmak; yardımlaşmak' (Tietze, 2016: 589) anlamında ikinci bir elleş- daha vardır. Bu iki eşyazımlı sözcük farklı kökenlere dayanıyor olabilir. Yazarın zikrettiği elleşmuhtemelen él 'ülke, devlet' (Wilkens, 2021: 253a) kelimesine dayanmaktadır: elleş- < él+leş- < *él+le+ş- ‘*(birlikte) ülke fethetmek' $\rightarrow$ 'savaşmak'. Diğer elleş-'e gelince, daha önce bir makalemde Kırgızca elde- 'uzlaşmak' fiilinin Eski Türkçede tanıklanmamış bir *elle- 'mutabakata varmak' fiiline dayandığından bahsetmiştim (2020b: 59-60). Eski Türkçedeki elleş- 'antlaşmak, uzlaşmak' 
(Clauson, 1972: 153b) bu *elle- fiiline dayanıyor olmalıdır. Günbedkavus yazmasındaki elleş- de Eski Türkçe elleş- 'antlaşmak, uzlaşmak' fiilinden başka bir şey değildir. Son olarak, yazarın önerisinin soylamanın bağlamına da uygun olmadığını belirtmeliyim. Günbedkavus yazması ile Dede Qorqut Og்uzname yazmalarındaki soylamada 10 aşamalık savaş öncesi bir hazırlık ritüeli tasvir edilmiştir. Qazan Bey 10 aşamanın hiçbirinde mücadeleye girişmemiş, yani savaşmamıştır. 10 aşamalık bir ritüelin ardından Allah'a dua edip 'savaşmaya kalkışmıştır'. Dolayısıyla yazarın iddia ettiği gibi ritüelin 5. aşamasında Qazan Beyin elleşme'si, yani ‘savaşmasının, çarpışmasının' soylamanın bağlamına uygun olmadığı net olarak anlaşılmaktadır. Netice itibariyle, Günbedkavus yazmasında el vérüb elleş-in 'razı olup el sıkışmak' anlamına geldiği konusunda bir şüphe olmadığı rahatlıkla söylenebilir.

Yazar, bir notunda (s. 97, 99, vd.), Dede Qorqut anlatmalarındaki şahıs adı Uruz Beg'i Oruz Beg olarak okumaktadır. Bildiğim kadarıyla bu öneri Dede Qorqut araştırmacıları tarafından kabul görmemiştir. Yakında çıkacak bir makalemde Uruz şahıs adını ayrıntılı olarak ele alacağım için bu konu üzerinde fazla durmayacağım.

Metin bölümünde (s. 108-229), yazmanın orijinal resmi sayfanın sol tarafında, metnin yazıçevrimi de sağ tarafında verilmiştir. Böyle bir tertip tercihi isabetli olmuştur. Metnin aktarmasının da aynı sayfada bulunması şüphesiz okuyucu açısından daha faydalı olabilirdi.

Yazıçevrimde bazı kelimelerin koyu punto ile gösterildiği görülüyor. Yazar, bu sıra dışı uygulamayı niçin yaptığını Ön Söz'de şöyle açıklıyor: “Metindeki şiirsel söyleyişe dikkat çekmek amacı ile cümlelerdeki bazı ögeler ile özellikle tekrar edilmiş olan ahenk unsuru ögeler" (s. 8) koyu harfle gösterilmiştir. Açıkçası koyu puntolu yerlerin okuyucunun gözünü yorduğunu itiraf etmeliyim, ancak yazarın bu uygulaması aslında başka bir sorunu daha doğurmuştur. Metnin yazıçevrimi sanki metnin tamamı manzummuş gibi mısralar hâlinde sunulmuştur. Böyle bir tercih soylamalar kısmında makul karşılansa da yazmanın neredeyse tamamının manzummuş gibi sunulması doğru olmamıştır.

Ercilasun, Günbedkavus yazması keşfedildikten sonra yazmanın dili üzerinde inceleme yapmış ve metnin XVIII. yüzyıl Azerbaycan Türkçesine göre okunması gerektiğini söyleyip bunun için bazı ilkeler belirlemiştir (2019a ve 
2019b). Eserde, metnin okunuşu için Ercilasun'un ilkelerinin kabul edildiği söylense de (s. 8), bu ilkelere her zaman bağlı kalındığı söylenemez. Mesela, ekmeğine okunacak yerde ekmegine (2/11 [s.111]) veya seğirdiben okunacak yerde segirdiben (48/3 [s. 203]), vd. şeklinde okunması gibi.

Metin'den sonra Dil İçi Çeviri başlığı altında metnin aktarması (s. 231-262), sonra da metnin genel Dizin'i (s. 264-331) ile Özel Adlar Dizin'i (s. 333-340) bulunmaktadır. Eser, Kaynaklar bölümü (s. 341-347) ile sona ermektedir.

Bazı okuma ve anlamlandırmalara da kısaca değinmek istiyorum:

2/5’teki (s. 111) mevize éyler okunuşu ( $\rightarrow 6 / 1,22 / 6$, vd.) mevize éler şeklinde düzeltilmelidir. Daha önce belirtildiği üzere (Azemoun, 2020: 647, 649), Azerbaycan Türkçesinde yardımcı fiil olarak et-'den ziyade éle- 'etmek, eylemek' kullanılmaktadır (Orucov et al., 2006/II: 21b). Zaten asıl metindeki <AYLR> yazımının yazarın düşündüğü gibi éyle- şeklinde okunması da mümkün değildir.

3/2'deki (s. 113) péǵamber okunuşu $(\rightarrow 26 / 3)$ peyǵamber şeklinde düzeltilmelidir, zira Farsça peyġam-ber sözünün ne Azerbaycan Türkçesinde ne de Türkmencede böyle bir telaffuzuna rastlanmamaktadır.

3/2-3’teki pégamberüy bir dişini şehìd éşidüb öz otuz iki dişine kelbeteyn saldı (s. 113) cümlesi "Peygamberin bir dişini şehit işitip kendi otuz iki dişine kerpeten saldı" (s. 232) şeklinde aktarılmıştır. Aktarmadaki anlam net olarak anlaşılmıyor. Cümlenin "Peygamber' in bir dişinin şehit olduğunu duyunca kendi otuz iki dişini kerpetenle çeken" şeklindeki anlaşılır bir aktarması için bk. Azmun, 2019: 68.

3/11'deki ( $\rightarrow$ 25/1-2 ve 49/10-11) ada basa yériyendę (s. 113) ifadesi 'sert adımlarla yürüdüğünde’ (s. 233, 264b) ile anlamlandırılmıştır. Yazmanın aslında $<$ YYRYNDĄ> şeklinde yazılan kelimenin yériyendę ile okunması isabetli olmuştur. Bugün Azerbaycan Türkçesinde yéri- fiili (Orucov et al., 2006/III: 587a) 'adım atmak, hareket etmek, kımıldamak' gibi bir anlamda tanıklanmışır. İfadenin başındaki ada önemli bir tanıktır, çünkü adım sözünün ad- 'adım atmak' şeklindeki kökünü burada açıkça görebiliyoruz. Tabii ki ad-ìlk Türkçe *āt-şekline dayanmaktadır ve ad- uzun ünlünün tesiriyle sonradan meydana gelmiştir (Stachowski, 2019: 53b). Ancak, ada basa yériyendę'nin 'adım atıp hareket ettiğinde’ ile anlamlandırılmasının bağlama daha uygun olacağı kanaatindeyim. Bu anlamlandırma için krş. Nağısoylu, 2021: 256. 
3/13'teki (s. 113) emmüsi okunuşu 'amūsl (< 'amū+sı 'amcası') şeklinde düzeltilmelidir. Kelime açıkça Arapça aslındaki gibi ayın ile yazılmıştır. Doğru okuma için bk. Azmun 2019: 27.

5/3'teki (s. 117) yād okunuşu ( $\rightarrow$ 29/5, vd.) yad 'yabanc1' şeklinde düzeltilmelidir. Eski Türkçe yat kelimesi (Clauson, 1972: 882b) zaten uzun ünlünün etkisiyle yad olmuştur. Buradaki ünlü artık uzun değildir. Yazarın okuduğu $y \bar{a} d$ ise Farsça kökenli 'hatıra, anma' anlamındaki bambaşka bir sözcüktür.

6/7'deki (s. 119) göğ okunuşu ( $\rightarrow 7 / 2,10 / 11, v d$.) gök 'gök' şeklinde düzeltilmelidir. Yazarın okuduğu göğ şeklindeki bir okuyuş tarihî metinlerin hiçbirinde geçmez.

7/2'deki (s. 121) ıldırım okunuşu ildırım şeklinde düzeltilmelidir. (Ayrıca s. 81'deki açıklama). Kelime bugün Azerbaycan Türkçesinde ildırım şeklinde (Orucov et al., 2006/II: 527b) kullanılmaktadır. Bu arada eserin dizininde ıldırım sözcüğü bulunmamaktadır.

7/4'deki (s. 121) dest degirmi ibaresi doğru anlamlandırılmıştır, ancak ibarenin okunuşu desdegirmi şeklinde düzeltilmelidir (Azemoun, 2020: 655). Muhtemelen yazıcı yazımda bir hata yapmış veya ibareyi anlayamamıştır. İbarenin aslı desdegirmi olmalıdır, yani baştaki des- ikili tekrarın ilk parçasını meydana getirmektedir. Krş. testekerlek.

10/5'teki (s. 127) yelken bulut okunuşu yélgin bulut şeklinde düzeltilmelidir (Azemoun, 2020: 655). Krş. Eski Türkçe yelgin 'hızlı' (Clauson, 1972: 928a).

10/14'teki (s. 127) bedev okunuşu ( $\rightarrow$ 13/11, 21/11, vd.) bedöv şeklinde düzeltilmelidir (Azemoun, 2020: 650). Farsça bedev bedov 'hızlı at' anlamına gelen söz Azerbaycan Türkçesinde bedöv bedöy (Orucov et al., 2006/I: 267a) şeklinde yaşamaktadır.

11/2'deki (s. 129) sayban okunuşu ( $\rightarrow$ 22/9, vd.) sāybān şeklinde düzeltilmelidir (Azemoun, 2020: 648). Farsçada sāye-bān ve sāybān 'gölgelik' anlamıyla iki şekilde de kullanılmaktadır.

11/9'daki (s. 129) ag̀ın 'ak' (s. 236) anlamında değil, aġın 'tamamen, olduğu gibi, alabildiğine' anlamında olmalıdır (Azemoun, 2020: 660). Krş. Türkmence aǵın (Orucov et al., 2006/I: 37b). 


\section{0}

11/9-10'daki (s. 129) dìn kilidi okunuşu ve 'din kilidi' anlamlandırması (s. 236) bağlamda anlamlı durmamaktadır. Muhtemelen buradaki ibare deyn kilidi 'borç anahtarı' olmalıdır (Azemoun, 2020: 660).

14/8'deki (s. 135) tabl-bāzī ( $\rightarrow$ 18/14) okunuşu tabl-ı bāzı 'av kuşu için çalınan davul' şeklinde düzeltilmelidir (Azemoun, 2020: 661). Ayrıca sondaki /ī/ nispet i’si değil, yükleme hâli ekidir.

16/9'daki (s. 139) alavar (< Türkçe ala + Farsça vār) okunuşu ve 'alaca' anlamlandırması (s. 239, 266a) Elvār şeklinde düzeltilmelidir (Azemoun, 2020: 662), zira Elvār Arapça Lor'un çoğulu, Elvār tāzī ise 'Lor halkının yetiştirdiği tazı türü' olmalıdır.

16/13'teki (s. 139) éyle okunuşu ( $\rightarrow 17 / 2$, vd.) éle 'öyle' şeklinde düzeltilmelidir (Azemoun, 2020: 650). Krş. Azerbaycan Türkçesi éle 'öyle' (Orucov et al., 2006/II: 20b-21b).

17/4'teki (s. 141) kerenaylar okunuşu kernāylar 'belli törenlerde çalınan deliği olmayan çok uzun üflemeli bir müzik aleti' şeklinde düzeltilmelidir (Azemoun, 2020: 663).

18/1'deki (s. 143) darır okunuşu darar şeklinde düzeltilmelidir. Yazar, dartfiiline 'gelmek, rastlamak' anlamı vermekte ve Moğolca dāgari- ile ilişkilendirmek istemektedir (s. 279a). Halbuki Türkmencede dara- fiili ‘saldırmak' anlamında yaşamaktadır (Kyýasowa et al., 2016/I: 253a). Ayrıca soylamanın redif dizisinin \{-Ar\} geniş zaman ekiyle kurulduğuna da dikkat edilmelidir.

18/3'teki (s. 143) omrır okunuşu omrar şeklinde düzeltilmelidir. Yazar, omrtfiiline dizinde 'incinmek, ezilmek, zedelenmek' anlamı vermiştir (s. 309b). Türkmencede omur- fiili (Kyýasowa et al., 2016/II: 140a) 'ikiye bölmek, ezmek' anlamıyla yaşamaktadır. Buna göre, omrar yazımı omur-ar şeklinde tahlil edilmelidir. Orta hece ünlüsü / $\mathrm{u} /$ vurgusuz olduğu için düşmüştür.

18/6'daki (s. 143) sügsün ( $\rightarrow$ 23/3) okunuşu süksün şeklinde düzeltilmelidir. Krş. TS/V: süksün 'boyun kökü, ense' (3617-3618).

19/4'teki (s. 145) bildırçın okunuşu $(\rightarrow \quad 30 / 14)$ bildirçin şeklinde düzeltilmelidir (Azemoun, 2020: 665). Krş. Azerbaycan Türkçesi bildirçin 'bıldırcın' (Orucov et al., 2006/I: 303b). 
22/8'deki (s. 151) ölen okunuşu ölen şeklinde düzeltilmelidir. Ayrıca dizinde kelimenin Moğolca kökenli olarak gösterilmesi de doğru değildir, zira aksine Türkçe öley, Moğolcaya ödünç verilmiştir (Doerfer, 1965: 161). Yazar, dizinde kendi kaydettiği Doerfer'in açılamasını muhtemelen okumamış olmalıdır.

23/1'deki (s. 153) hürmet okunuşu hörmet şeklinde düzeltilmelidir. Krş. Azerbaycan Türkçesi hörmet (Orucov et al., 2006/II: 401b).

23/5'teki (s. 153) dom şeşperler ( $\rightarrow$ 59/1) okunuşu düm şeşperler şeklinde düzeltilmelidir (Azemoun, 2020: 667), zira bu ibarede geçen düm Farsçada 'büyük kırbaç' anlamındadır. Yazarın dizinde 'pek, sert' anlamıyla kaydettiği dum (282a) diye bir söz Türk dillerinde yoktur.

23/9'daki (s. 153) <ADRBAYCAN> kelimesinin $(\rightarrow 35 / 13,36 / 6,52 / 6)$ yazmada dört yerde de dal ile yazımı düşündürücüdür. Kelime zel ile yazılması beklenirken kelimenin dal ile noktasız yazımı burada bir yazım hatası olduğu ihtimalini zayıflatmaktadır. Ažerbāycān adının ilk kısmının Farsça āzzar 'ateş' anlamına gelen sözle ilgili olduğu daha önce pek çok kişi tarafından ileri sürülmüştür. Aslında 'ateş' anlamına gelen sözün Farsçada ādar şekli de malumdur. Günbedkavus yazmasının müstensihi veya sözlü ortamı muhtemelen bunu tercih etmiş olmalıdır.

23/13'teki (s. 153) Arasilan okunuşu ( $\rightarrow$ 50/8, 51/9) Eres ilen 'Aras ile' şeklinde düzeltilmelidir (Azemoun, 2020: 667), zira metinde elif in üstünde med değil, fetha vardır. Böylece Aras nehrinin adı Farsçada telaffuz edildiği gibi yazılmıştır.

25/14'deki (s. 157) söletmiş okunuşu söyletmiş şeklinde düzeltilmelidir, zira muhtemelen yazıcı vav'dan sonra ye'yi yazmayı unutmuş olmalıdır. Ne Türkmencede ne de Azerbaycan Türkçesinde sölet- diye bir fiile rastlanmaz.

27/1'deki (s. 161) qurçı başı okunuşu qorçı başı şeklinde düzeltilmelidir. Kelime hakkında daha geniş bilgi için bk. Doerfer 1963: 429-432.

27/10'daki éller içmez bulanduruq sası suyu sülenmez mi (s. 161) cümlesi, "Eller içmez bulanık tuzlu suyu dilenmez mi?” (s. 245) ile aktarılmıştır. Dizinde sası için Clauson'un sözlüğüne dayanılarak 'kötü kokulu, kokuşmuş, pis' (s. 315a) anlamı verilmiştir. Buradaki sası'yı 'tatsız' olarak anlamlandırmak belki daha doğru olabilir. Kelimenin 'tatsız' anlamı için krş. Anadolu Ağızları sası (DS/X: 3549a). 


\section{ग(৫)}

Ayrıca, sası 43/13'te de geçmektedir ve orada da su'yu nitelemektedir. İnsanların 'pis ve kokmuş' suya değil, 'tatsız' suya talim etmek zorunda kalmış olması bağlama göre daha muhtemel gözükmektedir.

28/3-4'deki yükinde kölügine osal baxan éller yurtdan köçende partalcuğı qara yurdun bucağında qaralmaz mı (s. 163) "Göçünde yük hayvanına hor bakan, eller yurttan göçtüğünde (kendi) göçü kara yurdun bucağında kararmaz mı?” (s. 245) ile aktarılmıştır. Bu cümlede 'kararacak' olan 'kendi göçü’ değil, göçten mahrum kalan partalçuq'tur. Yazar, dizinde partal'a 'yatak, göç yükü' anlamı vermiş ve partalcuq'u partal'ın altında maddeleştirmiş̧tir (s. 312a), ancak burada ana madde partalçuq olmalıdır. Yazar anlamlandırmasında Derleme Sözlüğü'ndeki 'ev eşyası' kaydını (DS/IX: 3402a) esas almış olmalıdır. Bu anlamlandırma muhtemelen doğrudur. Günbedkavus yazmasındaki partal'ın göçüşmeli şekli paltar 'kıyafet, giysi' Azerbaycan Türkçesinde (Orucov et al., 2006/III: 569a) tanıklanmıştır. Yazmadaki partalçuq'un Azerbaycan Türkçesindeki tanığa göre anlamlandırılıp anlamlandırılamayacağı hakkında kesin bir şey söyleyemiyorum.

28/5'teki (s. 163) tülüngisen okunuşu tülengisen şeklinde düzeltilmelidir (Azemoun, 2020: 668). Buradaki tülengī Farsça tuleng+ī 'muhtaç, dilenci' olmalıdır.

29/13'teki (s. 165) bühtān okunuşu ( $\rightarrow$ 30/2) böhtān şeklinde düzeltilmelidir. Krş. Azerbaycan Türkçesi böhtān (Orucov et al., 2006/I: 346b).

31/1-2'deki (s. 169) ġanim olup yüz ag்artmaq 'düşman olup gururlanmak' hiç de mantıklı görünmüyor. Bunun yerine, daha önce önerildiği gibi (Azmun, 2019: 47, dip. 76) alup'un yanlışlıkla olup olarak yazıldığı varsayılırsa, ġanim alup yüz aǵartmaq 'düşmanı ele geçirip gururlanmak' anlamlı hâle gelmektedir.

33/9'daki (s. 173) dégricegi okunuşu digiricegi (< digirik+cek+i) şeklinde düzeltilmelidir (Azemoun, 2020: 670). Türkmencenin Atabay ağzında diğirrik 'kalça kemiği' demektir.

37/2'deki (s. 181) dorlaq okunuşu durlaq şeklinde düzeltilmelidir. Krş. Eski Türkçe turlaq 'zayıf' (Clauson, 1972: 546b).

40/4'deki (s. 187) tiken okunuşu tikan şeklinde düzeltilmelidir. Krş. Azerbaycan Türkçesi tikan ‘diken' (Orucov et al., 2006/IV: 339b).

41/5'teki (s. 189) buzav okunuşu buzov şeklinde düzeltilmelidir. Krş. Azerbaycan Türkçesi buzov 'buzağı' (Orucov et al., 2006/I: 368a). 


\section{ग(๑)}

42/10'daki (s. 191) yıġılalar okunuşu ve 'toplanıp' okunuşu (s. 252) bağlamda anlamsız duruyor, bu nedenle okunuş yıqulırlar 'yıkılırlar, elden ayaktan düşerler' şeklinde düzeltilmelidir. Kelimedeki ikinci $r a$ harfi yazmada he gibi gözükse de aslında yazıcı kelimeyi satırın sonuna sığdırmak zorunda kaldığı için ra'nın kuyruğunu biraz kısa tutmuştur.

47/4-5’teki (s. 201) gözin aydın quldırur okunuşu görin aydın quldurur şeklinde düzeltilmelidir (Azemoun, 2020: 670). Burada yazarın düşündüğü gibi ze'nin noktası unutulmamıştır. Farsça gūr 'mezar' sözcügüu Türkmencede bugün gōr (Kyýasowa et al., 2016/I: 471a) olarak yaşamaktadır. Metinde 'mezarın nurlanmasından' bahsedilmektedir.

50/13'teki (s. 207) yanıl okunuşu yayıl 'sarıya çalan hafif kırmızı' şeklinde düzeltilmelidir (Azemoun, 2020: 660). Krş. DS/XI: yảal 'kırmızı, pembeleşmiş' (4159b).

51/3’teki (s. 209) tibde okunuşu tipde şeklinde düzeltilmelidir, zira kelime açıkça üç noktalı pe ile yazılmıştır.

52/7-8'deki tazı tula yéddürdi bahrī quşlar götürtdi ala parslar ögürtdi (s. 211) cümlesi “Tazı tula(yı) yedeğinde götürdü, gökdoğanlar yanına aldırttı, ala parslar öne geçirtti” (s. 257) şeklinde aktarılmıştır. Buradaki yéddür- fiilinin sözlük anlamı yazarın anlamlandırmada kullandığı 'yedeğinde götürmek' olsa da bağlama göre yéddürdi'yi 'yanına aldırttı' olarak aktarmak belki daha doğru olacaktır. Yazar, götürtdi'yi 'yanına aldırttı' ile aktarmıştır, ancak buradaki fiil götür-fiilinin ettirgen gövdesidir. Eski Türkçede kötür-fiilinin 'kaldırmak, yukarı yükseltmek' (Clauson, 1972: 706a) anlamında olduğu bilinmektedir. Metinde bahrī quşlar da zaten av için 'yukarı yükseltilip' uçurulmuştur. Bu nedenle, götürt-in 'kaldırtmak, av için (kuş) uçurtmak' gibi bir anlamı bağlama daha uygundur. Yazmada, <AWNKRTDY> şeklinde yazılan kelime ögürtdi (s. 211) şeklinde okunmuş ve 'öne geçirtti' (s. 257) ile anlamlandırılmıştır. Yazarın tahmin ettiği ögürt- fiiline Azerbaycan Türkçesinde ve Türkmencede rastlanmaz. Bu kelime muhtemelen Türkmencedeki öyürt- 'önüne geçmek' (Kyýasowa et al., 2016/II: 168a) fiili olmalıdır. Bu nedenle, kelimenin öyürtdi şeklinde okunup ‘önüne kattı’ ile anlamlandırması gerekmektedir.

60/6'daki gümür gümür danış (s. 227), aktarmada "gümbür gümbür konuş" (s. 261) ile anlamlandırılmıştır. Soylamadaki bağlama bakınca Qazan'ın neden 
'gümbür gümbür' konuşması gerektiği anlaşılmıyor. Bence burada <KWMWR> şeklinde yazılan söz gümbür olamaz, zira bu söz Türkmencede gümmür şeklinde yaşamaktadır. Orijinal yazmada mim'in üzerinde bir şedde bulunmadığına göre gümür okunuşu doğrudur, ama bu gümür'ün anlamı 'gümbür' olamaz. Burada başka bir kelime düşünülmelidir. Krş. Anadolu Ağızları gümür gümür qonuş‘biriyle samimi ve güzel konuşmak' (Derleme Sözlüğü: 2254a), Türkmence gümür yamır 'samimice, dostça' (Kyýasowa et al., 2016/I: 508a). Soylamadaki bağlama göre de gümür gümür tekrarı 'samimice, açık açı' anlamında olmalıdır, zira Qara Budaq emmisi Qazan'dan kendisiyle 'samimice, açık açık' konuşmasını talep etmektedir.

Son olarak, yazmadaki bir imlâ özelliğine değinmek istiyorum. Yazmada, bazı aslı/y/'li olan sözlerin nun ile yazıldığı görülüyor. Bu imlâ özelliği yazmanın Azerbaycan coğrafyasında yazılmış olabileceğini akla getirmektedir, zira bugün standart Azerbaycan Türkçesinde /y/'ler kaybolmuştur (Ercilasun 2019b: 14). Ancak yazıcı bazı kelimelerde /y/ ünsüzünü nun kef veya sadece kef ile yazmaya devam etmiştir. Bu kelimelerin okunuşunda /y/'yi yazıçevrime yansıtmak daha doğru olacaktır. Mesela, deniz $\rightarrow$ dejiz (23/3, vd.), gén $\rightarrow$ géy (2/9, vd.), könül $\rightarrow$ kögül (6/1, vd.), mana $\rightarrow$ mana (54/6, vd.), ögçe $\rightarrow$ öyçe (23/1), ögümde $\rightarrow$ öyümde (49/9), öginde $\rightarrow$ öjinde (51/8), öginden $\rightarrow$ öyinden (12/8), sonra $\rightarrow$ sogra (10/9, vd.), sügüler $\rightarrow$ süjüler (18/2), vd.

Türkiye ve Azerbaycan'da ağılıklı olmak üzere Türk dünyasının her yerinde Dede Qorqut anlatmaları hakkında hatırı sayılır bir araştırma külliyatı oluşmuştur. Anlatmaların nasıl yaratıldığı başta olmak üzere anlatmaların içerik sorunları ile elimize ulaşan yazmalardaki filolojik sorunlar üzerine literatür her geçen gün hızla büyümektedir. Dede Qorqut anlatmalarının daha iyi anlaşılması adına yapılacak çalışmaların hepsi şüphesiz birbirinden değerlidir. Günbedkavus yazmasının daha iyi anlaşılması için sarf ettiği gayretten ötürü yazarı tebrik ederim.

\section{Kaynakça}

Axundov, A. A. et al. (2007). Azerbaycan Dilinin Dialektoloji Lüğeti A-Z. Bakı: "ŞerqQerb". 


\section{0}

Azemoun, Y. (2013). Türkmencede Sonu /-k/ ve /-ňk/ ile Biten Bazı Yansıma Sözcüklerin Sonuna Gelen Bir Ek Üzerinde İnceleme. Türk Dili Araştırmaları Yıllığı Belleten, 61(2), 167-182.

Azemoun, Y. (2020). Kitab-1 Türkmen'de Türkmence Sözcükler. Çukurova Üniversitesi Türkoloji Araştırmaları Dergisi, 5(2), 642-679.

Azmun, Y. (2019). Dede Korkut'un Üçüncü Elyazması, Soylamalar ve İki Yeni Boy İle Türkmen Sahra Nüshası, Metin-Çeviri-Sözlük-Tıpkıbasım. İstanbul: Kutlu Yayınevi.

Clauson, Sir G. (1972). An Etymological Dictionary of Pre-Thirteenth Century Turkish. Oxford: Oxford University Press.

Doerfer, G. (1963). Türkische und Mongolische Elemente im Neupersischen, unter besonderer Berücksichtigung älterer Neupersischer Geschichtsquellen, vor allem der Mongolenund Timuridenszeit I. Wiesbaden: Franz Steiner Verlag.

Doerfer, G. (1965). Türkische und Mongolische Elemente im Neupersischen, unter besonderer Berücksichtigung älterer Neupersischer Geschichtsquellen, vor allem der Mongolenund Timuridenszeit II. Wiesbaden: Franz Steiner Verlag.

Ercilasun, A. B. (2019a). Dede Korkut'un Yeni Nüshas1 Üzerine/Konu-BağlantılarYer-Zaman-Okuyuş. Dil Araştırmaları, 24, 7-13.

Ercilasun, A. B. (2019b). Dede Korkut Kitabı'nın Yeni Nüshası ve Üzerindeki Yayınlar. Milli Folklor, 123, 5-22.

Erdal, M. (1991). Old Turkic Word Formation: a Functional Approach to the Lexicon I-II. Wiesbaden: Harrassowitz Verlag.

İslamov, M. (1968). Azerbaycan Dilinin Nuxa Dialekti. Bak1: Azerbaycan SSR Élimler Akadémiyası Neşriyatı.

Kincses-Nagy, É. (2018). Mongolic Copies in Chaghatay. Wiesbaden: Harrassowitz Verlag.

Kyýasowa, G. et al. (2016). Türkmen Diliniň Düşündirişli Sözlügi I-II. Aşgabat: Ylym.

Nağısoylu, M. (2021). Kitabi-Dede Qorqud’un Gönbed Élyazmasl: Tékstoloji-Filoloji Araşdırma, Tenqidi Metn, Sözlük. Bakı: Élm və Təhsil.

Orucov, E. et al. (2006). Azerbaycan Dilinin İzahlı Lüğeti I-IV. Bakı: Şerq-Qerb.

Özçelik, S. (2016). Dresden Nüshası, Metin, Dizin. Ankara: Türk Dil Kurumu Yayınları.

Qafarlı, R. \& Rzasoy, S. (2019). Kitabi-Dədə Qorqud'un Üçüncü Jlyazması, Yoxsa “Kitabi-Türkmən Lisani” Oğuznaməsi. Dədə Qorqud, 65(II), 3-39. 


\section{0}

Ramstedt, G. J. (1935). Kalmückisches Wörterbuch. Helsinki: Suomalais-Ugrilainen Seura.

Räsänen, M. (1969). Versuch eines etymologischen Wörterbuchs der Türksprachen. Helsinki: Suomalais-Ugrilainen Seura.

Shahgoli, N. K. et al. (2019). Dede Korkut Kitabı'nın Günbet Yazmasi: İnceleme, Metin, Dizin ve Tıpkıbasım. Modern Türklük Araştırmaları Dergisi, 16(2), 147-379.

Stachowski, M. (2019). Kurzgefaßtes etymologisches Wörterbuch der türkischen Sprache. Kraków: Księgarnia Akademicka.

Tezcan, S. (2001). Dede Korkut Oğuznameleri Üzerine Notlar. İstanbul: Yapı Kredi Yayınları.

Tezcan, S. (2020). Topkapı Sarayı Oğuznamesi, İnceleme. İstanbul: Yapı Kredi Yayınları.

Tietze, A. (2016). Tarihî ve Etimolojik Türkiye Türkçesi Lugatı II. Eds. Demir, N. \& Y1lmaz, E. Ankara: Türkiye Bilimler Akademisi.

Tulu, S. (2020). Dede Korkut Oğuznâmesi -Boylar ve Soylamalar-Günümüz Türkçesine Sözlü Çevirisi, Dresden Nüshası ve Günbed-i Kâvus/Türkmensahra Elyazması Esasında. Ankara: Nobel Akademik Yayıncılı.

Türkiye’de Halk Ağzından Derleme Sözlüğü (1993). 12 Cilt. II. Baskı. Ankara: Türk Dil Kurumu Yayınları. ( $\rightarrow$ DS)

Uçar, E. (2017). Notizen zur Etymologie des alttürkischen özäl- ,sich quälen‘. Central Asiatic Journal, 60(1), 1-11.

Uçar, E. (2019). Dede Korkut Anlatmalarındaki Ban Üzerine. Anasay, 10, 21-42.

Uçar, E. (2020a). Dede Korkut Kitabı'ndaki Bir Soylama Üzerine. Eski Türk Edebiyatı Araştırmaları Dergisi, 3(1), 213-240.

Uçar, E. (2020b). Kırgızca eldik (I) ‘halk, millet, kalabalık’ ve eldik (II) ‘barış, uzlaşı, demokrat' Sözlerinin Yapısı Üzerine. In Kocaoğlu, T. (Ed.), Türk Söz ve Kültür Varlıklarının İzinde (pp. 57-61). İstanbul: Kutlu Yayınevi.

Wilkens, J. (2021). Handwörterbuch des Altuigurischen, Altuigurisch-Deutsch-Türkisch. Göttingen: Universitätsverlag Göttingen.

XIII. Yüzyıldan Beri Türkiye Türkçesiyle Yazılmış Kitaplardan Toplanan Tanıklarıyla Tarama Sözlüğü (1995). 8 Cilt. III. Baskı. Ankara: Türk Dil Kurumu Yayınları. ( $\rightarrow$ TS) 